\title{
Destruction of azo dyes by anaerobic-aerobic sequential biological treatment: a review
}

\author{
S. Popli • Upendra. D. Patel
}

Received: 6 September 2013/Revised: 17 November 2013/Accepted: 11 January 2014/Published online: 12 February 2014

(C) Islamic Azad University (IAU) 2014

\begin{abstract}
Dyes are synthetic organic compounds widely used in various industries such as, textile, leather, plastic, food, pharmaceutical, and paints manufacturing industries. Coloured effluents are highly toxic to the aquatic life and mutagenic to humans. Wastewater containing dyes has become an important issue demanding serious attention. Among the synthetic dyes, azo dyes are the largest and most widely used dyes and account for more than half of the annually produced dyes. The biodegradation of azo dyes is difficult due to their complex structure and synthetic nature. Several treatments have been proposed for efficient azo dye removal, most of them presenting some limitations such as generation of waste sludge, high operational costs, poor efficiency, and incomplete mineralization. Biological treatment is a cost-effective and eco-friendly process for dye degradation. Sequential anaerobic-aerobic biological treatment is considered as one of the most cost-effective methods for the complete mineralization of azo dyes. The anaerobic stage yields decolourization through reductive cleavage of the dye's azo linkages, resulting in the formation of generally colourless but potentially hazardous aromatic amines. The aerobic stage involves degradation of the aromatic amines. It is the most logical step for removing the azo dyes from the wastewater. Several factors can influence the microbial activity and consequently the efficacy and effectiveness of the complete biodegradation processes. This paper
\end{abstract}

S. Popli

Civil Engineering Department, C S Patel Institute of Technology, Charotar University of Science \& Technology, Changa, Dist-Anand 388421, Gujarat, India

Upendra. D. Patel $(\square)$

Civil Engineering Department, Faculty of Technology \& Engineering, The M. S. university of Baroda, Vadodara, India e-mail: patelupendra@gmail.com summarizes the results of biological decolourization of azo dyes using various types of reactors, elaborates biochemical mechanisms involved, and discusses influence of various operational parameters on decolourization based on reports published in the last decade.

Keywords Azo dyes - Biodegradation - Anaerobic decolourization - Aromatic amines - Operating parameters . Toxicity

\section{Introduction}

Dyes are substances capable of colouring fabrics which cannot be removed by rubbing or washing (Sharma 2011). Organic synthetic dyes have been widely used as colourants in different industries such as textile, paper, colour photography, pharmaceutical, food, cosmetics, and photoelectrochemical cell (Forgacs et al. 2004). More than 0.7 million tons of organic synthetic dyes are produced yearly, worldwide (Johnstrup et al. 2011). In addition, over 10,000 different dyes are known and have their applications in various industries. Studies indicate that approximately $10 \%$ of synthetic dyes produced per year are lost to the environment during manufacturing and processing operations (Sandhya et al. 2005). Dyes are classified according to their application and chemical structure. It is composed of a group of atoms responsible for the dye colour, called chromophores, as well as an electron withdrawing or donating substituents that cause or intensify the colour of the chromophores, called auxochromes. The most important chromophores are azo $(-\mathrm{N}=\mathrm{N}-)$, carbonyl $(-\mathrm{C}=\mathrm{O})$, ethylene $(-\mathrm{C}=\mathrm{C}-)$, carbon nitrogen group $(-\mathrm{C}=\mathrm{NH}-)$, nitro $\left(-\mathrm{NO}_{2}-\right)$, and quinoid groups. The most important auxochromes are amines $\left(-\mathrm{NH}_{2}\right)$, carboxyl $(-\mathrm{COOH})$, sulphonate $\left(-\mathrm{SO}_{3} \mathrm{H}\right)$, 
and hydroxyl $(-\mathrm{OH})$. The auxochromes can belong to the classes of reactive, acid, direct, basic, mordant, disperse, sulphur, and vat dyes based on method of application (Iqbal 2008; Hunger 2009). Azo dyes are the largest group of dyes used in textile industry constituting $60-70 \%$ of all dyestuff produced. Azo dyes are characterized by the presence of one or more azo bonds ( $\mathrm{R} 1-\mathrm{N}=\mathrm{N}-\mathrm{R} 2)$ connecting aromatic rings. Different substitutions on aromatic nucleus give structurally diverse and most versatile group of compounds which makes them recalcitrant and xenobiotic (Ali 2010). These complex aromatic substituted structures make conjugated system and are responsible for intense colour, high water solubility, and resistance to degradation of azo dyes under natural conditions (Khan et al. 2013; Senthikumar et al. 2012). Figure 1 gives an illustration of the chemical structure of several azo dyes widely reported in the published literature. The wastewater originated from azo dye manufacturing is reported to pass unaffected through conventional treatment systems (Iqbal 2008; Hunger 2009). In addition to high organic content, the textile wastewater exhibits low BOD/COD ratios $(<0.1)$ (Hao et al. 2000; Oller et al. 2011). Generally, azo dyes are not considered to be toxic to humans. Chronic effects are associated with those who work in textile processing units. The cleavage of azo bonds in azo dyes results in formation of aromatic amines, which can act as mutagens. Azo dyes accidentally consumed by humans are biochemically reduced by microbes present in the gastrointestinal tract leading to formation of dye intermediates that act as carcinogens by forming acyl oxy amines via N-hydroxylation and can initiate bladder cancer. Aromatic amines may further be reduced to nitrenium and carbonium ions which can anchor with DNA and RNA, and consequently end in mutation of the nucleic acids, and formation of tumours (Chequer et al. 2011; Johnstrup et al. 2011; Puvaneshwari et al. 2006).

Thus, removal of dyes from wastewater is desired not only for aesthetic reasons and environmental threats they pose, but also because many azo dyes and their breakdown products are toxic to aquatic life and hazardous to humans.

\section{Decolourization and degradation of dyes by various methods}

Decontamination of dye effluents has been a major concern to the community since a long time. Various types of treatment processes that can be used to treat the dye-containing wastewater are physicochemical and biological<smiles>O=[N+]([O-])c1cc(S(=O)(=O)O)cc2ccc(O)c(N=Nc3ccccc3)c12</smiles>

Orange G
Monoazo dyes<smiles>N#[W]OS(=O)(=O)c1ccc(N=Nc2c(O)ccc3ccccc23)cc1</smiles>

Diazo dyes

Reactive

Black 5

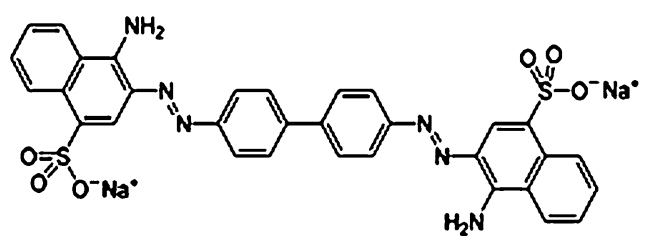

Triazo dyes

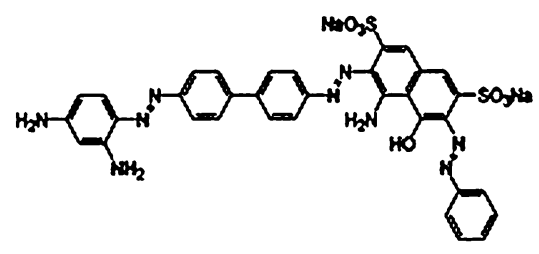

Direct Black 38

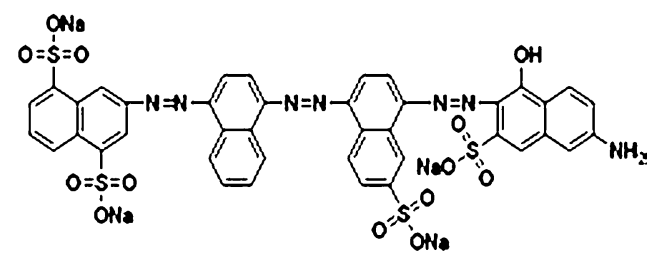

Direct Blue 71

Fig. 1 Chemical structures of some azo dyes with varying numbers of azo bonds 
processes. Physical processes include adsorption (Amin 2008; Anjaneyulu et al. 2005; Malik 2003; Velmurugan et al. 2011) and membrane filtration (Patel and Nath 2012; Petrinic et al. 2007) processes. Chemical processes include coagulation-flocculation (Wong et al. 2007; Golob et al. 2005) and ozonation (Taplad et al. 2008; Inaloo et al. 2011). Advanced oxidation processes (AOP) include Fenton's reagent (Meric et al. 2005; Gutowska et al. 2007; Koprivanac and Kusic 2009), photo-Fenton (Khan et al. 2010), and photocatalysis (Daneshwar et al. 2003; Mashkour et al. 2011). Electrochemical processes include electrocoagulation (Phalakornkule et al. 2010; Daneshvar et al. 2007; Patel et al. 2011), electrooxidation (Chou et al. 2011; Costa et al. 2009), and electrochemical reduction (Uliana et al. 2012). The procedures mentioned above lead to effective decolourization, but their application is restricted due to various reasons; for example, physical processes lead to phase transfer of dye and no destruction. The adsorbent material needs to be regenerated and dyes recovered have to be disposed. Chemical processes are rapid but non-selective. They often require costly chemicals/reagents and produce sludge containing hazardous products (Martinez-Huitle and Brillas 2009). Biological treatment may present a relatively inexpensive and environment-friendly alternative producing less sludge and requiring lesser amount of reagents. Besides being economical in nature, it can lead to complete mineralization of dyes (Pandey et al. 2007; Rai et al. 2005; Khan et al. 2013). Removal of pollutants from the environment by biological methods has significant advantages over other methods because of the adaptability of various micro-organisms in degrading various compounds. Azo dyes can undergo biological degradation under both aerobic and anaerobic conditions (Vanderzee et al. 2001). This paper reviews various biological systems for decolourization of azo dyes using mixed microbial culture and various types of laboratory scale reactors. It also examines influence of various operational parameters on decolourization, discusses toxicity at various stages of biological treatment, and illustrates biochemical mechanisms involved in anaerobicaerobic sequential biodegradation of azo dyes.

Decolourization of dyes: pure versus mixed microbial cultures

There are two possible ways of dye decolourization during a biological treatment: (1) adsorption on the microbial biomass and (2) biodegradation of dyes by microbial cells. Adsorption of dye is referred to as biosorption because it occurs on growing, living, and dead biomaterial. In biosorption, the dye structure is not destroyed but entrapped into the microbial biomass. Thus, it may not be a practical solution for treating dye-containing wastewater because of the difficulty in disposal of the microbial biomass containing adsorbed dyes. Biomass adsorption is advantageous when the dye-containing wastewater is toxic and effective when conditions are not favourable for the growth and maintenance of the microbial population (Robinson et al. 2001). Biodegradation is a preferred process in which the azo dye structure is destroyed resulting in generation of aromatic amines and sometimes achieves complete mineralization, i.e. conversion into $\mathrm{CO}_{2}, \mathrm{H}_{2} \mathrm{O}$, and some inorganic salts (Ali 2010). A huge variety of micro-organisms, such as, bacteria, fungi, yeasts, and algae, are capable of decolourizing different dyes. They have shown different capabilities for degrading different dyes (Fu and Viraraghvan 2001). The effectiveness of microbial decolourization depends on the adaptability and activity of the selected micro-organisms (Adinew 2012). A complete review on degradation of dyes by various micro-organisms has been published in recent years (Saratale et al. 2011; Solis et al. 2012; Chengalroyen and Dabbs 2013). As compared to pure microbial cultures which are vulnerable to contamination, mixed microbial cultures, such as anaerobic granular sludge or aerobic activated sludge, have more applicability in actual field conditions for wastewater treatment. It is also advantageous to use mixed culture because of high microbial diversity that helps to decrease toxicity effect and enhance process stability by resisting variation in quality and quantity of wastewater. Thus, the mixed microbial consortia can carry out tasks better than or equivalent to that of an individual pure culture without any precautions to prevent contamination. Different reactor configurations, such as the widely used upflow anaerobic sludge blanket (UASB), expanded granular sludge bed (EGSB), anaerobic/aerobic sequential batch reactor (SBR), activated sludge process (ASP), have been reported for efficient dye decolourization using mixed microbial consortia (Dos Santos et al. 2007; Karatas et al. 2010; Yasar et al. 2012; Da Silva et al. 2012). The biodegradation of azo dyes occurs in a two-step process (Rai et al. 2005; Vanderzee et al. 2001). Azo linkages are easily reduced under anaerobic condition, yielding colourless aromatic amines, which are further degraded aerobically (Barraga et al. 2007). Therefore, sequential anaerobic-aerobic treatment holds a promise as a method to completely remove azo dyes from the wastewater. Table 1 shows various anaerobic-aerobic biological reactors used for destruction of azo dyes in the reported literature.

\section{Sequential anaerobic-aerobic biological treatment of azo dyes}

Factors influencing anaerobic decolourization

Decolourization of dyes under anaerobic condition is initiated by azoreductase-catalysed reduction or by cleavage 
Table 1 Results of decolourization of various azo dyes with respect to volumetric dye loading, dye concentration, HRT, and reactor type, obtained using mixed microbial culture

\begin{tabular}{|c|c|c|c|c|c|c|c|}
\hline Azo dye (type) & Reactor & $\begin{array}{l}\text { Dye } \\
\text { concentration } \\
(\mathrm{mg} / \mathrm{L})\end{array}$ & $\begin{array}{l}\text { HRT } \\
\text { (d) }\end{array}$ & $\begin{array}{l}\text { Volumetric loading of dye } \\
\text { (mg of dye/L volume of } \\
\text { reactor/day) }\end{array}$ & $\begin{array}{l}\% \\
\text { colour } \\
\text { removal }\end{array}$ & $\begin{array}{l}\text { First-order } \\
\text { reaction rate } \\
\text { constant }\left(\mathrm{h}^{-1}\right)\end{array}$ & References \\
\hline \multirow{3}{*}{$\begin{array}{l}\text { Remazol Red } \\
\text { RR (monoazo) }\end{array}$} & \multirow{3}{*}{$\begin{array}{l}\text { Anaerobic- } \\
\text { aerobic biofilm } \\
\text { glass reactor }\end{array}$} & 100 & 0.5 & 200 & 95 & \multirow[t]{3}{*}{ N.R } & \multirow{3}{*}{$\begin{array}{l}\text { Johnstrup et al. } \\
\text { (2011) }\end{array}$} \\
\hline & & 300 & 0.5 & 600 & 85 & & \\
\hline & & $500-2,000$ & 1.5 & 1,000 & 98 & & \\
\hline $\begin{array}{l}\text { Reactive Black } 5 \\
\text { (diazo) }\end{array}$ & UASB-CSAR & 150 & 3.42 & 43.85 & 99 & N.R & $\begin{array}{l}\text { Karatas et al. } \\
\text { (2010) }\end{array}$ \\
\hline \multirow{5}{*}{$\begin{array}{c}\text { Acid Red } 18 \\
\text { (monoazo) }\end{array}$} & \multirow{5}{*}{$\begin{array}{l}\text { SBR anaerobic- } \\
\text { aerobic }\end{array}$} & 35 & 2.75 & 12.63 & 67 & 0.0593 & \multirow{5}{*}{$\begin{array}{l}\text { Hakimelahi et al. } \\
\text { (2012) }\end{array}$} \\
\hline & & 70 & 2.75 & 25.26 & 61 & 0.0511 & \\
\hline & & 140 & 2.75 & 50.52 & 57 & 0.0414 & \\
\hline & & 280 & 2.75 & 101.04 & 56 & 0.0384 & \\
\hline & & 100 & 0.25 & 400 & 82 & N.R & \\
\hline \multirow{2}{*}{$\begin{array}{l}\text { Reactive } \\
\text { Brilliant Violet } \\
5 \text { (monoazo) }\end{array}$} & \multirow{2}{*}{$\begin{array}{l}\text { SBR anaerobic- } \\
\text { aerobic }\end{array}$} & 100 & 0.375 & 266.67 & 93 & \multirow[t]{2}{*}{ N.R } & \multirow{2}{*}{$\begin{array}{l}\text { Yasar et al. } \\
\text { (2012) }\end{array}$} \\
\hline & & 400 & 0.5 & 400 & 96.3 & & \\
\hline $\begin{array}{l}\text { Congo red } \\
\text { (diazo) }\end{array}$ & $\begin{array}{l}\text { UASB-aerobic } \\
\text { SBR }\end{array}$ & 200 & 1 & 400 & 75.2 & N.R & $\begin{array}{l}\text { Da Silva et al. } \\
\text { (2012) }\end{array}$ \\
\hline $\begin{array}{l}\text { Reactive Black } 5 \\
\text { (diazo) }\end{array}$ & $\begin{array}{l}\text { UASB-aerobic } \\
\text { SBR }\end{array}$ & 50 & 2 & 25 & 92.30 & N.R & $\begin{array}{l}\text { Da Silva et al. } \\
\text { (2012) }\end{array}$ \\
\hline $\begin{array}{l}\text { Reactive Black } 5 \\
\text { (diazo) }\end{array}$ & $\begin{array}{c}\text { Anaerobic SBR- } \\
\text { aerobic MBR }\end{array}$ & 100 & 3 & 33.33 & 40.9 & N.R & $\begin{array}{l}\text { You and Teng } \\
\text { (2009) }\end{array}$ \\
\hline $\begin{array}{l}\text { Orange G } \\
\quad(\text { monoazo })\end{array}$ & $\begin{array}{l}\text { UASB-agitated } \\
\text { aerobic tank } \\
\text { process }\end{array}$ & 100 & 3 & 33.33 & 51.3 & N.R & $\begin{array}{l}\text { Rajaguru et al. } \\
(2000)\end{array}$ \\
\hline $\begin{array}{l}\text { Amido black } \\
\text { (diazo) }\end{array}$ & $\begin{array}{l}\text { UASB-agitated } \\
\text { aerobic tank } \\
\text { process }\end{array}$ & 200 & 3 & 66.67 & 56.2 & N.R & \\
\hline $\begin{array}{l}\text { Direct red } \\
\text { (diazo) }\end{array}$ & $\begin{array}{l}\text { UASB-agitated } \\
\text { aerobic tank } \\
\text { process }\end{array}$ & 200 & 3 & 66.67 & 45.6 & N.R & \\
\hline $\begin{array}{l}\text { Congo red } \\
\text { (diazo) }\end{array}$ & $\begin{array}{l}\text { UASB-agitated } \\
\text { aerobic tank } \\
\text { process }\end{array}$ & 100 & 0.5 & 200 & 98 & N.R & \\
\hline $\begin{array}{c}\text { Acid Red } 88 \\
\text { (monoazo) }\end{array}$ & UFCR-CSAR & 100 & 0.4375 & 228.5 & 99 & N.R & $\begin{array}{l}\text { Khehra and Saini } \\
\text { (2006) }\end{array}$ \\
\hline $\begin{array}{l}\text { Reactive } \\
\text { Brilliant } \\
\text { Violet-5 } \\
\text { (monoazo) }\end{array}$ & $\begin{array}{l}\text { SBR anaerobic- } \\
\text { aerobic }\end{array}$ & 25 & 0.4375 & 57.14 & $\begin{array}{l}\text { Very } \\
\text { low }\end{array}$ & N.R & $\begin{array}{l}\text { Albuquerque } \\
\text { et al. (2005) }\end{array}$ \\
\hline $\begin{array}{l}\text { Acid Orange7 } \\
\text { (monoazo) }\end{array}$ & $\begin{array}{l}\text { SBR anaerobic- } \\
\text { aerobic }\end{array}$ & 100 & 1.25 & 81.12 & 97 & N.R & $\begin{array}{l}\text { Albuquerque } \\
\text { et al. (2005) }\end{array}$ \\
\hline \multirow{7}{*}{$\begin{array}{l}\text { Reactive Black } 5 \\
\text { (diazo) }\end{array}$} & \multirow[t]{7}{*}{ UASB-CSTR } & 100 & 0.654 & 159.84 & 82 & \multirow[t]{7}{*}{ N.R } & \multirow{7}{*}{$\begin{array}{l}\text { Sponza and Isik } \\
\text { (2002) }\end{array}$} \\
\hline & & 100 & 0.433 & 229.92 & 95 & & \\
\hline & & 100 & 0.3375 & 310.56 & 92 & & \\
\hline & & 100 & 0.208 & 480.00 & 85 & & \\
\hline & & 100 & 0.158 & 631.92 & 87 & & \\
\hline & & 100 & 0.125 & 799.92 & 87 & & \\
\hline & & 100 & 1 & 100 & 72 & & \\
\hline \multirow{3}{*}{$\begin{array}{l}\text { Reactive } \\
\text { Brilliant } \\
\text { Violet-5R } \\
\text { (monoazo) }\end{array}$} & \multirow{3}{*}{$\begin{array}{l}\text { SBR anaerobic- } \\
\text { aerobic }\end{array}$} & 100 & 0.5 & 200 & 89 & \multirow[t]{3}{*}{0.364} & \multirow{3}{*}{$\begin{array}{l}\text { Cinar et al. } \\
\text { (2008) }\end{array}$} \\
\hline & & 100 & 0.25 & 400 & 86 & & \\
\hline & & 100 & 2 & 50 & $>95$ & & \\
\hline
\end{tabular}


Table 1 continued

\begin{tabular}{|c|c|c|c|c|c|c|c|}
\hline Azo dye (type) & Reactor & $\begin{array}{l}\text { Dye } \\
\text { concentration } \\
(\mathrm{mg} / \mathrm{L})\end{array}$ & $\begin{array}{l}\text { HRT } \\
\text { (d) }\end{array}$ & $\begin{array}{l}\text { Volumetric loading of dye } \\
\text { (mg of dye/L volume of } \\
\text { reactor/day) }\end{array}$ & $\begin{array}{l}\% \\
\text { colour } \\
\text { removal }\end{array}$ & $\begin{array}{l}\text { First-order } \\
\text { reaction rate } \\
\text { constant }\left(\mathrm{h}^{-1}\right)\end{array}$ & References \\
\hline $\begin{array}{c}\text { Acid Red } 88 \\
\text { (monoazo) }\end{array}$ & FB-SBBR & 100 & 2.75 & 36.36 & 72 & 0.449 & $\begin{array}{l}\text { Koupaie et al. } \\
\text { (2013) }\end{array}$ \\
\hline \multirow{3}{*}{$\begin{array}{c}\text { Acid Red } 88 \\
\text { (monoazo) }\end{array}$} & \multirow{3}{*}{$\begin{array}{l}\text { AN-SBR MB- } \\
\text { SBBR }\end{array}$} & 500 & 2.75 & 181.81 & 89 & 0.236 & \multirow{3}{*}{$\begin{array}{l}\text { Koupaie et al. } \\
\text { (2012) }\end{array}$} \\
\hline & & 1,000 & 2.75 & 363.63 & 86 & 0.286 & \\
\hline & & 100 & 1 & 100 & 100 & N.R & \\
\hline $\begin{array}{l}\text { Remazol } \\
\text { Brilliant } \\
\text { Orange 3R } \\
\text { (monoazo) }\end{array}$ & $\begin{array}{l}\text { Batch anaerobic- } \\
\text { aerobic reactor }\end{array}$ & 100 & 1 & 100 & 78.9 & N.R & $\begin{array}{l}\text { Supaka et al. } \\
\text { (2004) }\end{array}$ \\
\hline $\begin{array}{l}\text { Remazol black B } \\
\text { (diazo) }\end{array}$ & $\begin{array}{l}\text { Batch anaerobic- } \\
\text { aerobic reactor }\end{array}$ & 100 & 1 & 100 & 100 & N.R & $\begin{array}{l}\text { Supaka et al. } \\
\text { (2004) }\end{array}$ \\
\hline $\begin{array}{l}\text { Remazol } \\
\text { Brilliant } \\
\text { Violet-5R } \\
\text { (monoazo) }\end{array}$ & $\begin{array}{l}\text { Batch anaerobic- } \\
\text { aerobic reactor }\end{array}$ & 3,200 & 3.6 & 888.88 & 77 & N.R & $\begin{array}{l}\text { Supaka et al. } \\
\text { (2004) }\end{array}$ \\
\hline $\begin{array}{l}\text { Direct Black } 38 \\
\text { (triazo) }\end{array}$ & UASB-CSTR & 3200 & 0.625 & 254.1 & 100 & N.R & $\begin{array}{l}\text { Isik and Sponza } \\
\text { (2004) }\end{array}$ \\
\hline \multirow[t]{6}{*}{$\begin{array}{l}\text { Direct Black } 38 \\
\text { (triazo) }\end{array}$} & \multirow[t]{6}{*}{ UASB-CSTR } & 3,200 & 0.680 & 541.67 & $>90$ & N.R & $\begin{array}{l}\text { Sponza and Isik } \\
(2005)\end{array}$ \\
\hline & & 3,200 & 0.641 & $1,058.33$ & 80 & & \\
\hline & & 3,200 & 0.666 & $2,166.67$ & 80 & & \\
\hline & & 3,200 & 0.641 & $4,445.83$ & 80 & & \\
\hline & & 3,200 & 0.625 & 8,875 & 80 & & \\
\hline & & 25 & 1 & 25 & 55 & & \\
\hline \multirow[t]{2}{*}{$\begin{array}{l}\text { Reactive Orange } \\
16 \text { (monoazo) }\end{array}$} & \multirow{2}{*}{$\begin{array}{l}\text { Anaerobic- } \\
\text { anoxic-aerobic } \\
\text { reactor }\end{array}$} & 25 & 3.85 & 6.49 & 90 & N.R & $\begin{array}{l}\text { Spagni et al. } \\
\text { (2010) }\end{array}$ \\
\hline & & 100 & 0.875 & 114.2 & 80 & & \\
\hline $\begin{array}{l}\text { Disperse Blue } 79 \\
\text { (monoazo) }\end{array}$ & $\begin{array}{l}\text { SBR anaerobic- } \\
\text { aerobic }\end{array}$ & 533 & 2.6 & 205 & 94 & N.R & $\begin{array}{l}\text { Melgoza and } \\
\text { Buitron (2004) }\end{array}$ \\
\hline $\begin{array}{l}\text { Remazol Black } \\
\text { B (diazo) }\end{array}$ & $\begin{array}{l}\text { SBR anaerobic- } \\
\text { Aerobic }\end{array}$ & 60 & 0.25 & 240 & 90 & N.R & $\begin{array}{l}\text { Shaw et al. } \\
\text { (2002) }\end{array}$ \\
\hline $\begin{array}{l}\text { Remazol Red } \\
\text { RR (monoazo) }\end{array}$ & $\begin{array}{l}\text { SBR anaerobic- } \\
\text { Aerobic }\end{array}$ & 300 & 1 & 300 & 94 & N.R & $\begin{array}{l}\text { Kapdan and } \\
\text { Oztekin (2006) }\end{array}$ \\
\hline $\begin{array}{l}\text { Remazol } \\
\text { Brilliant Violet } \\
\text { 5R (monoazo) }\end{array}$ & FBR & 150 & 1 & 150 & 98.9 & 0.173 & $\begin{array}{l}\text { Sen and Demierer } \\
\quad(2003)\end{array}$ \\
\hline \multirow{5}{*}{$\begin{array}{l}\text { Reactive Black } 5 \\
\text { (diazo) }\end{array}$} & \multirow{5}{*}{$\begin{array}{l}\text { Anaerobic batch } \\
\text { reactor }\end{array}$} & 300 & 1 & 300 & 99.4 & 0.190 & \multirow{5}{*}{$\begin{array}{l}\text { Karatas et al. } \\
\text { (2009) }\end{array}$} \\
\hline & & 600 & 1 & 600 & 99.2 & 0.177 & \\
\hline & & 1,200 & 1 & 1,200 & 98.3 & 0.153 & \\
\hline & & 2,400 & 1 & 2,400 & 93.4 & 0.110 & \\
\hline & & 150 & 1 & 150 & 99.8 & 0.248 & \\
\hline \multirow{5}{*}{$\begin{array}{l}\text { Reactive Red } 24 \\
\text { (monoazo) }\end{array}$} & \multirow{5}{*}{$\begin{array}{l}\text { Anaerobic batch } \\
\text { reactor }\end{array}$} & 300 & 1 & 300 & 99.4 & 0.199 & \multirow{5}{*}{$\begin{array}{l}\text { Karatas et al. } \\
\text { (2009) }\end{array}$} \\
\hline & & 600 & 1 & 600 & 95.6 & 0.135 & \\
\hline & & 1,200 & 1 & 1,200 & 96.6 & 0.139 & \\
\hline & & 2,400 & 1 & 2,400 & 94.9 & 0.123 & \\
\hline & & 100 & 10 & 10 & $>99$ & N.R & \\
\hline $\begin{array}{l}\text { Acid Orange } 7 \\
\text { (monoazo) }\end{array}$ & $\begin{array}{l}\text { Batch anaerobic- } \\
\text { aerobic reactor }\end{array}$ & 100 & 10 & 10 & $>99$ & N.R & $\begin{array}{l}\text { Manu and } \\
\text { Chaudhari } \\
\text { (2002) }\end{array}$ \\
\hline
\end{tabular}


Table 1 continued

\begin{tabular}{|c|c|c|c|c|c|c|c|}
\hline Azo dye (type) & Reactor & $\begin{array}{l}\text { Dye } \\
\text { concentration } \\
(\mathrm{mg} / \mathrm{L})\end{array}$ & $\begin{array}{l}\text { HRT } \\
\text { (d) }\end{array}$ & $\begin{array}{l}\text { Volumetric loading of dye } \\
\text { (mg of dye/L volume of } \\
\text { reactor/day) }\end{array}$ & $\begin{array}{l}\% \\
\text { colour } \\
\text { removal }\end{array}$ & $\begin{array}{l}\text { First-order } \\
\text { reaction rate } \\
\text { constant }\left(\mathrm{h}^{-1}\right)\end{array}$ & References \\
\hline $\begin{array}{l}\text { Reactive Black } 5 \\
\quad(\text { diazo) }\end{array}$ & $\begin{array}{c}\text { Batch anaerobic- } \\
\text { aerobic reactor }\end{array}$ & 0 & 1.25 & 0 & 100 & 0.0062 & $\begin{array}{l}\text { Manu and } \\
\text { Chaudhari } \\
(2002)\end{array}$ \\
\hline \multirow{6}{*}{$\begin{array}{l}\text { Direct Black } 38 \\
\text { (triazo) }\end{array}$} & \multirow{6}{*}{$\begin{array}{c}\text { Batch anaerobic- } \\
\text { aerobic reactor }\end{array}$} & 200 & 1.25 & 160 & 20 & 0.0056 & \multirow{6}{*}{$\begin{array}{l}\text { Sponza and Isik } \\
\text { (2004) }\end{array}$} \\
\hline & & 400 & 1.25 & 320 & 10 & 0.0051 & \\
\hline & & 800 & 1.25 & 640 & 10 & 0.0021 & \\
\hline & & 1,600 & 1.25 & 1,280 & 10 & 0.0016 & \\
\hline & & 3,200 & 1.25 & 2,560 & 10 & 0.0017 & \\
\hline & & 100 & 1 & 100 & 99 & 0.950 & \\
\hline \multirow{2}{*}{$\begin{array}{l}\text { Reactive Black } 5 \\
\text { (diazo) }\end{array}$} & \multirow{2}{*}{$\begin{array}{l}\text { Spent GAC } \\
\text { biofilm SBR }\end{array}$} & 200 & 1 & 200 & 94 & 0.978 & \multirow[t]{2}{*}{ Ong et al. (2012) } \\
\hline & & 100 & 0.25 & 400 & $>80$ & N.R & \\
\hline $\begin{array}{l}\text { Remazol } \\
\text { Brilliant Violet } \\
\text { 5R (monoazo) }\end{array}$ & $\begin{array}{l}\text { Anaerobic- } \\
\text { aerobic SBR }\end{array}$ & 30 & 0.83 & 36.14 & 100 & N.R & Cirik et al. (2012) \\
\hline \multirow{4}{*}{$\begin{array}{l}\text { Reactive Red } 2 \\
\text { (monoazo) }\end{array}$} & \multirow{4}{*}{$\begin{array}{l}\text { Anaerobic ABR- } \\
\text { aerobic FAS } \\
\text { reactor }\end{array}$} & 100 & 0.83 & 120.38 & 87 & \multirow[t]{4}{*}{ N.R } & \multirow{4}{*}{$\begin{array}{l}\text { Naimabadi et al. } \\
\text { (2009) }\end{array}$} \\
\hline & & 250 & 0.83 & 301.20 & 85 & & \\
\hline & & 350 & 0.83 & 421.68 & 85 & & \\
\hline & & 100 & 2 & 50 & 92 & & \\
\hline \multirow{3}{*}{$\begin{array}{l}\text { Orange } 2 \\
\quad(\text { monoazo) }\end{array}$} & \multirow{3}{*}{$\begin{array}{l}\text { Sulphidogenic } \\
\text { bioreactor }\end{array}$} & 500 & 2 & 250 & 89 & \multirow[t]{3}{*}{ N.R } & \multirow{3}{*}{$\begin{array}{l}\text { Mutambanengwe } \\
\text { et al. (2007) }\end{array}$} \\
\hline & & 1,000 & 2 & 500 & 53 & & \\
\hline & & 100 & 2 & 50 & 89 & & \\
\hline \multirow{3}{*}{$\begin{array}{l}\text { Reactive Black } 5 \\
\text { (diazo) }\end{array}$} & \multirow{3}{*}{$\begin{array}{l}\text { Sulphidogenic } \\
\text { bioreactor }\end{array}$} & 500 & 2 & 250 & 86 & \multirow[t]{3}{*}{ N.R } & \multirow{3}{*}{$\begin{array}{l}\text { Mutambanengwe } \\
\text { et al. (2007) }\end{array}$} \\
\hline & & 1,000 & 2 & 500 & 50 & & \\
\hline & & 100 & 2 & 50 & 88 & & \\
\hline \multirow{3}{*}{$\begin{array}{l}\text { Amido Black } 10 \\
\text { (diazo) }\end{array}$} & \multirow{3}{*}{$\begin{array}{l}\text { Sulphidogenic } \\
\text { bioreactor }\end{array}$} & 500 & 2 & 250 & 60 & \multirow[t]{3}{*}{ N.R } & \multirow{3}{*}{$\begin{array}{l}\text { Mutambanengwe } \\
\text { et al. (2007) }\end{array}$} \\
\hline & & 1,000 & 2 & 500 & 40 & & \\
\hline & & 100 & 2 & 50 & 64 & & \\
\hline \multirow{3}{*}{$\begin{array}{c}\text { Reactive Red } \\
120 \text { (diazo) }\end{array}$} & \multirow{3}{*}{$\begin{array}{l}\text { Sulphidogenic } \\
\text { bioreactor }\end{array}$} & 500 & 2 & 250 & 64 & \multirow[t]{3}{*}{ N.R } & \multirow{3}{*}{$\begin{array}{l}\text { Mutambanengwe } \\
\text { et al. (2007) }\end{array}$} \\
\hline & & 1,000 & 2 & 500 & 50 & & \\
\hline & & 250 & 5 & 50 & 98 & & \\
\hline \multirow{7}{*}{$\begin{array}{l}\text { Simulated mixed } \\
\text { azo dye waste }\end{array}$} & \multirow{7}{*}{$\begin{array}{l}\text { Two-phase } \\
\text { anaerobic } \\
\text { packed bed } \\
\text { reactor }\end{array}$} & 350 & 5 & 70 & 98 & & Talarposhti et al. \\
\hline & & 500 & 5 & 100 & 97.5 & & \\
\hline & & 600 & 5 & 120 & 97.2 & & \\
\hline & & 750 & 5 & 150 & 96.7 & & \\
\hline & & 900 & 5 & 180 & 94 & & \\
\hline & & 1,000 & 5 & 200 & 87 & & \\
\hline & & 1,200 & 5 & 240 & 73 & & \\
\hline
\end{tabular}

$U A S B-C S A R$ upflow anaerobic sludge blanket-continuously stirred aerobic reactor, $S B R$ sequencing batch reactor, $M B R$ membrane bioreactor, $U F C R$ upflow fixed-film column reactor, $F B-S B B R$ fixed-bed sequencing batch biofilm reactor, $A N$ - $S B R$ anaerobic sequential batch reactor, $M B$ $S B B R$ moving bed sequencing batch biofilm reactor, $F B R$ fluidized bed reactor, $G A C$ granular activated carbon, $A B R$ anaerobic baffled reactor, $F A S$ fixed activated sludge reactor, N.R. not reported

of azo bonds resulting in formation of aromatic amines by a mixed bacterial community (Sponza and Isik 2005). Extent of anaerobic biological colour removal has been reported to be higher than $80 \%$ and in some cases even $100 \%$ for a variety of azo dyes (Karatas et al. 2010; Yasar et al. 2012; Da Silva et al. 2012). The extent and rate of anaerobic decolourization of azo dyes are influenced by various parameters such as dye structure, dye concentration, supplementation with different carbon and nitrogen sources, electron donor, and redox mediator (Vanderzee and Villaverde 2005; Da Silva et al. 2012; Johnstrup et al. 2011; Koupaie et al. 2011; Mohanty et al. 2006; Albuquerque et al. 2005). The influence of each parameter is discussed as below. 


\section{Dye structure}

It has been observed that the degradation of a dye is highly influenced by its structure. Azo dyes are electron-deficient molecules which can undergo degradation via azo reduction. Rate of decolourization is affected by molecular weight, substitution groups of the dye molecules, number of azo bonds, and intermolecular hydrogen bonds between the azo and hydroxyl groups (Johnstrup et al. 2011; Lourenco et al. 2001; Panswad and Luangdilok 2000). Azo compounds with a hydroxyl or amino groups are more likely to be degraded than those with methyl, methoxy, sulpho, or nitro groups (Supaka et al. 2004). It has been reported that dyes with simple structures and low molecular weights exhibit higher rates of decolourization than those with high molecular weight and high substitutions (Solis et al. 2012; Da Silva et al. 2012). Colour removal efficiency of different types of dyes is different in similar reactors and under identical experimental conditions. Da Silva et al. (2012) studied decolourization of Congo red (CR) and Reactive Black 5 (RB5) in a UASB reactor under similar operating conditions and reported decolourization efficiency of 96.3 and $75 \%$, respectively, for CR and RB5. The lesser decolourization of RB5 was attributed to its high molecular weight and highly substituted chemical structure as compared to that of CR (see Fig. 1). Supaka et al. (2004) reported $100 \%$ colour removal for Remazol Brilliant Orange 3R (a monoazo dye) and $78.9 \%$ for RB5 (a diazo dye) under identical operating conditions in an anaerobic SBR. Lourenco et al. (2001) reported $90 \%$ colour removal for Remazol Brilliant Violet 5R (a monoazo dye, concentration of azo bond $=0.133 \mathrm{mM}$ ) and $75 \%$ colour removal for Remazol Black B (a diazo dye, concentration of azo bond $=0.06 \mathrm{mM}$ ) indicating that although at a lower initial concentration/number of azo bonds, a diazo dye is more resistant to decolourization than a monoazo dye at higher initial concentration.

\section{Hydraulic retention time (HRT)}

There is a direct relationship between the HRT of the anaerobic biological treatment unit and the colour removal efficiencies (Johnstrup et al. 2011; Karatas et al. 2010; Da Silva et al. 2012; Oh et al. 2004; Spagni et al. 2010). For instance, Johnstrup et al. (2011) reported increase in the extent of decolourization of Remazol Red RR (initial concentration: $100 \mathrm{mg} / \mathrm{L}$ ) from 85 to $98 \%$ when HRT of anaerobic batch reactor was increased from 0.5 to 3 days. Yasar et al. (2012) employed an SBR consisting of cyclic anaerobic-aerobic conditions for decolourization for Remazol Brilliant Violet 5R (RBV 5R). The authors reported that the decolourization efficiencies were $72 \%$ for HRT of $3 \mathrm{~h}, 87 \%$ for HRT of $6 \mathrm{~h}$, and $92 \%$ for HRT of
$9 \mathrm{~h}$ with rest of experimental conditions being constant. The authors attributed increase in decolourization efficiency with increasing HRT to increased activity of azoreductase enzymes responsible for bond cleavage. On the other hand, lower initial biomass concentration and solids retention time (SRT) may result in considerable decrease in colour removal efficiency irrespective of HRT or dye concentration (Lourenco et al. 2001). Thus, a biological reactor with a higher biomass retention capacity (e.g. UASB) might be better suited for azo dye decolourization than that with a lower biomass retention capacity (e.g. SBR) (Vanderzee and Villaverde 2005).

\section{Dye concentration}

The degradation of an azo dye is very much affected by the initial dye concentration. Varying concentration of different dyes have been tested, and lower concentrations (50-500 $\mathrm{mg} / \mathrm{L}$ ) have been reported to be best decolourized. High dye concentration may adversely affect the microbial growth and decrease the efficiency of microbial dye degradation process. Increasing dye concentration gradually decreases the decolourization rate, probably due to the toxic effects of dyes with regard to the individual bacteria and/or inadequate biomass concentration, as well as the blockage of active sites of azoreductase by dye molecules (Ali 2010). Similar results are also reported for a mixture of azo dyes (Talarposhti et al. 2001). In addition to this, the aromatic metabolites produced due to anaerobic dye decolourization may be inhibitory and toxic to anaerobic biomass. For example, Koupaie et al. (2011, 2012) reported that by increasing the concentration of Acid Red 18 from 100 to $500 \mathrm{mg} / \mathrm{L}$ in a moving bed sequencing biofilm batch reactor inhibited the growth and reduced the final mass of the attached growth biofilm. Bonakdarpour et al. (2011) found that decolourization in anaerobic condition decreased when dye concentration of RB5 increased from 100 to $500 \mathrm{mg} / \mathrm{L}$. Authors also observed that there was blue shift in the characteristic wavelength of RB5 after anaerobic treatment resulted from cleavage of only one of the two azo bonds of RB5. However, efficient decolourization may be achieved if either the microbial culture is pre-exposed to dye or sufficient HRT is provided so as to increase the concentration of enzymes. Johnstrup et al. (2011) studied decolourization of Reactive Red RR in an anaerobic attached growth column. It was reported that with increase in concentration of dye from 100 to $300 \mathrm{mg} / \mathrm{L}$ at HRT of 0.5 days, the colour removal efficiency decreased. However, when HRT was increased from 0.5 to 1.5 days for higher dye concentration $(300 \mathrm{mg} / \mathrm{L})$, the decolourization efficiency of $98 \%$ (equivalent to that achieved at lower dye concentration) was achieved. Table 1 lists results of decolourization of various azo dyes 
with respect to various operational parameters such as volumetric dye loading, dye concentration, and HRT.

\section{Alternative electron acceptor (and redox mediator)}

Anaerobic biological decolourization is a biochemical oxidation-reduction reaction. The most important point to be emphasized is availability of the electron acceptors in the anaerobic phase. As the anaerobic colour removal occurs by reduction of the azo dye which acts as final electron acceptor in the microbial electron transport chain, the presence of alternative electron acceptors in anaerobic zone can become a rate-controlling factor for the dye decolourization (Vanderzee et al. 2001). The electronaccepting process depends on the redox potential difference between the electron donor and electron acceptor (Dos Santos et al. 2007). The presence of alternative electron acceptors, such as oxygen, nitrate, sulphate, and ferric ion, may compete with the azo dye for reducing equivalents and results in insufficient colour removals under anaerobic condition. Figure 2 indicates the electron flow preferences in the presence of different redox couples involved in biological processes. Cirik et al. (2012) compared anaerobic colour removal rate constants for Remazol Brilliant Violet 5R in the presence and absence of nitrate. The authors noted decrease in decolourization from 93 to $63 \%$ with increase in concentration of nitrate from 0 to $113 \mathrm{mg} / \mathrm{L} \mathrm{NO}_{3}-\mathrm{N}$. It may be noted from Fig. 2 that energy required for nitrate reduction $\left(+740 \mathrm{mV}\right.$ for $\left.\mathrm{NO}_{3}^{-1} / \mathrm{NO}_{2}^{-1}\right)$ is much less than that required $(-430$ to $-180 \mathrm{mV})$ for reduction of azo dyes. Mohanty et al. (2006) investigated the effect of varying concentration of dissolved oxygen (DO) on decolourization of RB5. With increase in the concentration of DO from 0.5 to $3.0 \mathrm{mg} / \mathrm{L}$, the decolourization efficiency reduced from 96 to $19 \%$ indicating the interference of DO as a preferred electron acceptor as compared to RB5. The presence of sulphate as an alternative electron acceptor has been reported to have varying effects on decolourization of azo dyes. Sulphate may be reduced to sulphide by anaerobic bacteria (sulphatereducing bacteria) and thus compete with azo dyes for electrons. On the other hand, reduced sulphur species produced under anaerobic condition may directly reduce the azo bonds. Vanderzee et al. (2003) observed that the presence of sulphate at concentration as high as $60 \mathrm{mM}$ did not interfere with transfer of electrons to Reactive Red 2. Similarly, Albuquerque et al. (2005) did not notice any improvement in decolourization capacity for Acid Orange 7 in an anaerobic-aerobic SBR even though the presence of sulphate-reducing microbes was confirmed. These results indicate that sulphate may not compete as an electron acceptor with the azo dye (thus, no production of reduced sulphur species) or even if sulphate acts as an alternative electron acceptor, the biogenic sulphide does not contribute to the reduction of dye. Similarly, Cirik et al. (2012) observed that increasing the sulphate concentration from 0 to $480 \mathrm{mg} / \mathrm{L}$ did not have any significant effect on decolourization of RBV-5R after $6 \mathrm{~h}$ of anaerobic reaction time. However, the authors noted that with increase in sulphate concentration, the initial rate of decolourization also increased. It was hypothesized that the biogenic sulphide may act as an electron donor and in turn facilitates
Fig. 2 Reduction potential of some common redox couples (Source: Dos Santos et al. 2007; Cirik et al. 2012)

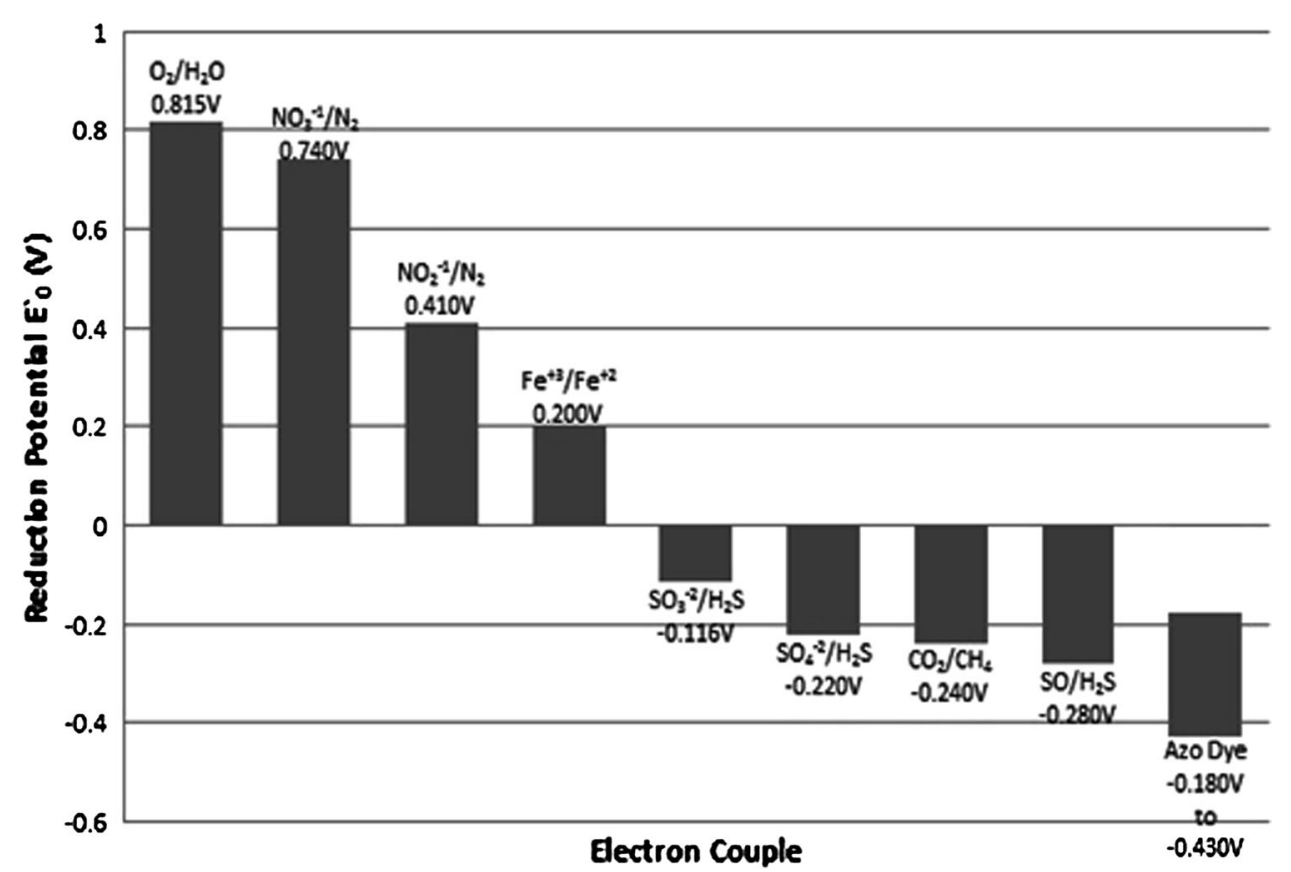


decolourization. Young-kim et al. (2007) demonstrated decolourization of RB5 in an actual textile wastewater containing high concentration of sulphate by augmentation of anaerobic sludge with sulphate-reducing bacteria, Desulfovibrio desulfuricans. The authors observed that decolourization using the sludge augmented with Desulfovibrio desulfuricans was $14 \%$ higher than the sludge without any augmentation. The increase in decolourization may be attributed to direct reduction of azo bonds by biogenic sulphide or indirect reduction via electron shuttles reduced by sulphide (Vanderzee and Cervantes 2009).

Redox mediator (RM) can accelerate the electron transfer from a primary electron donor to a terminal electron acceptor, which may increase the reaction rates. The RM compounds can be generated by the microbial metabolism or they may be added externally (Vanderzee and Cervantes 2009). Flavin-based compounds, such as flavinadenide dinucleotide (FAD) and flavinadenide mononucleotide (FMN), and quinone-based compounds, such as anthraquinone-2,6-disulphonate (AQDS), anthraquinone-2-sulphonate (AQS), riboflavin (vitamin B2), cyanocobalamin (vitamin B12), menadione (MQ), and lawsone (2-hydroxy-1,4-naphthoquinone), have been extensively reported as redox mediators (Saratale et al. 2011; Rauf and Salman Ashraf 2012; Albuquerque et al. 2005; Mendez-paz et al. 2005; Vanderzee et al. 2003). The use of redox mediators would tend not only to accelerate the transfer of reducing equivalents to the terminal electron acceptor, but also to minimize the steric hindrance of the dye molecules and to decrease the activation energy of the chemical reaction (Dos santos et al. 2007). The effect of redox mediator has been observed to be dependent on (1) the type of co-substrate, (2) temperature, (3) ratio of redox mediator/azo dye, and (4) the presence of trophic groups and selective inhibitors (Vanderzee and Cervantes 2009). Albuquerque et al. (2005) studied effect of the presence of various RMs on anaerobic decolourization of Acid Orange 7 (AO7). Only $5 \%$ decolourization could be achieved after $10 \mathrm{~h}$ of incubation in the absence of any RM. The decolourization increased to about $25 \%$ in the presence of $0.05 \mathrm{mM} \mathrm{MQ}$ and $\sim 75 \%$ in the presence of $0.05 \mathrm{mM}$ AQS. With further increase in concentration of AQS to $0.1 \mathrm{mM}$, extent of decolourization and rate of decolourization improved further. Boonyakamol et al. (2009) reported that in treating the methyl orange (MO) in batch anaerobic reactor, decolourization could not be accelerated by using the redox mediator alone. However, when small amount $(0.2 \mathrm{mM})$ of AQS was added, more than $90 \%$ decolourization was achieved. On the other hand, a high concentration of redox mediator $(1.0 \mathrm{mM})$ had an inhibitory effect on decolourization especially under thermophilic condition. In another study, Mendez-paz et al. (2005) investigated the decolourization of Acid Orange 7 (AO7) as a sole carbon source in a feed batch supply. It was reported that the rate of decolourization improved with successive batch treatment of AO7, i.e. in the first feeding, complete AO7 removal took place approximately in 20 days, while in the second and third feedings, complete decolourization was achieved in about 9 and 7 days, respectively. The authors hypothesized that improvement in decolourization rate in successive feedings was due to the presence of 1-amino 2-naphthol (generated as a product of azo bond cleavage of AO7) which acted as a redox mediator.

\section{Primary substrate type and its concentration}

In a process of microbial destruction of pollutants, the primary substrate helps in two ways: (1) As a source of energy and carbon for the growth and survival of microorganisms, and (2) as an electron donor for example, for cleavage of azo bonds in azo dyes and for $\mathrm{C}-\mathrm{Cl}$ bond in chlorinated organic compounds. Electrons obtained from oxidation of primary substrate are transferred to electronaccepting pollutants such as azo dyes directly or indirectly through redox mediators resulting in decolourization (Pandey et al. 2007; Saratale et al. 2011). The electrondonating primary substrates used in the reactor studies vary from simple substrates such as acetate, ethanol, yeast extract, and glucose, to more complex ones including relevant constituents of textile processing wastewaters such as starch, polyvinyl alcohol (PVA), and carboxymethylcellulose (CMC) (Carvalho et al. 2008; Koupaie et al. 2012; Laowansiri et al. 2008; Sen and Demierer 2003; Mezohegyi et al. 2007; Johnstrup et al. 2011; Manu and Chaudhari 2002; O' Neill et al. 2000). A given initial concentration of primary substrate to achieve decolourization of a given type of azo dye may not result in the similar extent of decolourization of a different type of azo dye at similar initial concentration (Rajaguru et al. 2000). Vijaya and Sandhya (2003) studied effect of the presence and absence of glucose as a primary substrate for anaerobic decolourization of methyl red (MR). It was reported that in the absence of glucose, maximum concentration of dye that could be decolourized was $100 \mathrm{mg} / \mathrm{L}$. However, in the presence of $200 \mathrm{mg} / \mathrm{L}$ of glucose, a higher concentration of MR (700 mg/L) could be decolourized. It has also been reported that the presence of sufficient concentration of glucose as a primary substrate increases the rate of decolourization (Mohanty et al. 2006; Mendez-paz et al. 2005). The primary substrate may influence azo dye reduction rates by changing enzymes and by stimulating specific group of micro-organisms in the mixed cultures. Thus, the type of substrate may affect both the rates of direct/indirect azo dye decolourization (Vanderzee and Cervantes 2009). In addition to this, the type of primary substrate is also 
shown to influence the kinetic relationship of decolourization. The decolourization of CI Reactive Red 141 (RR141) in the presence of modified starch (MS) and polyvinyl alcohol (PVA) as carbon sources followed firstorder kinetics while that with acrylic size (AS) as a carbon source followed zero-order kinetics. Moreover, with the same initial concentration of primary substrate, MS being a more biodegradable substrate than PVA and AS, yielded higher decolourization efficiency (Laowansiri et al. 2008).

Toxicity at various stages of anaerobic-aerobic biodegradation

It has been estimated that about $10 \%$ of the dye stuff used in the textile dyeing processes do not bind to fibres and are, therefore, released to the environment (Puvaneshwari et al. 2006). Thus, the dye-containing wastewater may be toxic due to inherent toxicity and mutagenicity of dyes. The reactive dyes and hydrolysed reactive dyes have a lower toxicity potential in aquatic organisms as compared to acid, basic and disperse dyes (Franciscon et al. 2009). Anaerobic decolourization by cleavage of azo bond generates aromatic amines, which are in some cases more toxic than the parent dyes. Anaerobic decolourization followed by aerobic biodegradation may or may not reduce toxicity (Puvaneshwari et al. 2006; Da Silva et al. 2012; Montano et al. 2008). Various authors have employed different types of toxicity tests to evaluate the toxicity of dye wastewater at different stages of biological treatments. Some of the widely used toxicity tests are ecotoxicity test using D. Magna and Vibro fischeri as test organisms, respiration inhibition assays, anaerobic toxicity assays (ATA), etc. (Wang et al. 2002; Da Silva et al. 2012). Ecotoxicity test with D. Magna is carried out by calculating $\mathrm{EC}_{50}$, i.e. concentration that causes $50 \%$ death or immobility of the initial number of indicator organism. Acute toxicity can be assessed using the Biotox bacterial bioluminescence assay, by determining the inhibitory effect that the sample has on the marine photo-bacteria Vibrio fischeri. The toxicity effect is quantified as the $\mathrm{EC}_{50}$ parameter (the concentration of toxicant that cause $50 \%$ decrease of light emission after $30 \mathrm{~min}$ of exposure) and can be expressed as dissolved organic carbon (DOC) units $(\mathrm{mg} / \mathrm{L}$ of $\mathrm{C})$. When the DOC of the sample is lower than the $\mathrm{EC}_{50}$, this is assumed to be non-toxic. In respiration inhibition test, a decrease in oxygen consumption to the control sample is measured. It is performed to assess the inhibitory effect of anaerobic and aerobic effluents on the activity of anaerobic/aerobic micro-organisms. In ATA, methanogenic activities of samples containing dye and its metabolites are compared to the control samples containing only glucose to determine the degree of inhibition. Inhibition is defined as a decrease in cumulative methane production compared to the control samples. Since all the tests consist of different procedures and use different test organisms, it is not possible to quantitatively compare the results of toxicity tests reported in the published literature. Hence, an attempt has been made to qualitatively show the results of toxicity assays published in the last decade (see Table 2). Contradictory reports are available in the published literature about toxicity of aqueous dye solutions at different stages of biological treatment. One of the reasons for contradictory results may be dissimilarity among toxicity analysis procedures, chemical structure of the dyes, and test organisms. For instance, Isik and Sponza (2004) reported increase in toxicity of raw effluent after anaerobic treatment and decrease in toxicity after aerobic treatment of anaerobic effluent using respiration inhibition test and eco-toxicity test. On the other hand, the authors reported for the same dye, in the same report, complete removal of initial toxicity after anaerobic and aerobic stages using anaerobic toxicity assay. Da Silva et al. (2012) reported toxicity of effluents at various stages of biodegradation of Congo red using ecotoxicity test using D. Magna. The study revealed that the effluent of anaerobic stage presented higher toxicity compared with the influent and an aerobic post-treatment was not efficient in reducing toxicity. However, in the same experimental conditions, the results with RB5 showed that both anaerobic and aerobic step could reduce dye toxicity. Therefore, the anaerobic-aerobic treatment may not always be effective in detoxifying all the azo dyes and not only that, it may also result in increase in dye toxicity as compared to the raw effluent.

Generation of aromatic amines under anaerobic condition and their fate during aerobic biological treatment

Azo dye decolourization due to anaerobic reduction results in the formation of aromatic amines (Pandey et al. 2007; Vanderzee and Villaverde 2005). The concentration and number of aromatic amines generated are found to be in accordance with the number of azo bonds in the chemical structure of the dye (Franciscon et al. 2009). Some of the evidences of amine generation were based on quantitative direct detection of individual compounds. However, this is possible with the use of sophisticated analytical techniques like liquid chromatography-mass spectrometry (LC-MS), gas chromatography-mass spectrometry (GC-MS), highperformance liquid chromatography (HPLC), GC, and UV-Vis spectroscopy (UV-Vis) (Yasar et al. 2012; Montano et al. 2008; Isik and Sponza 2004). If standards of the expected aromatic amines are not available, HPLC peaks cannot be identified and quantified directly, but the chromatographs can be useful to detect aromatic amines by comparing the retention time with standards of similar 
Table 2 Results of toxicity assays after anaerobic-aerobic biological treatment

\begin{tabular}{|c|c|c|c|c|c|}
\hline Azo dye studied & Method of evaluation & Influent & $\begin{array}{l}\text { Anaerobic } \\
\text { effluent }\end{array}$ & $\begin{array}{l}\text { Aerobic } \\
\text { effluent }\end{array}$ & References \\
\hline Congo red & Ecotoxicity with $D$. Magna & 0 & $\uparrow$ & $\uparrow$ & $\begin{array}{l}\text { Da Silva et al. } \\
\text { (2012) }\end{array}$ \\
\hline Reactive Black-5 & Ecotoxicity with $D$. Magna & $\uparrow$ & $\uparrow \uparrow$ & 0 & $\begin{array}{l}\text { Da Silva et al. } \\
\text { (2012) }\end{array}$ \\
\hline Cibacron Red FN-R & $\begin{array}{l}\text { Biotox bacterial bioluminescence assay with } \\
\text { Vibrio fischeri }\end{array}$ & 0 & $\uparrow$ & $\uparrow$ & $\begin{array}{l}\text { Montano et al. } \\
\text { (2008) }\end{array}$ \\
\hline $\begin{array}{l}\text { Reactive Black-5 (fully } \\
\text { hydrolysed) }\end{array}$ & $\begin{array}{l}\text { Biotox bacterial bioluminescence assay with } \\
\text { Vibrio fischeri }\end{array}$ & $\uparrow$ & $\uparrow \uparrow$ & $\downarrow$ & Libra et al. (2004) \\
\hline $\begin{array}{l}\text { Reactive Black-5 (partially } \\
\text { hydrolysed) }\end{array}$ & $\begin{array}{l}\text { Biotox bacterial bioluminescence assay with } \\
\text { Vibrio fischeri }\end{array}$ & $\uparrow$ & $\uparrow \uparrow$ & $\downarrow$ & Libra et al. (2004) \\
\hline Direct Black 38 & Respiration inhibition test & $\uparrow$ & $\uparrow \uparrow$ & $\downarrow$ & $\begin{array}{l}\text { Isik and Sponza } \\
\quad(2004)\end{array}$ \\
\hline Direct Black 38 & D. Magna & $\uparrow$ & $\uparrow \uparrow$ & $\downarrow$ & $\begin{array}{l}\text { Isik and Sponza } \\
\text { (2004) }\end{array}$ \\
\hline Direct Black 38 & Anaerobic toxicity assay & $\uparrow$ & 0 & 0 & $\begin{array}{l}\text { Isik and Sponza } \\
\quad(2004)\end{array}$ \\
\hline Remazol Yellow 107 & Ecotoxicity with $D$. Magna & $\uparrow$ & $\downarrow$ & 0 & $\begin{array}{l}\text { Franciscon et al. } \\
\text { (2009) }\end{array}$ \\
\hline Remazol Red 198 & Ecotoxicity with $D$. Magna & $\uparrow$ & $\downarrow$ & $\downarrow$ & $\begin{array}{l}\text { Franciscon et al. } \\
\text { (2009) }\end{array}$ \\
\hline Reactive Black 5 & Ecotoxicity with $D$. Magna & $\uparrow$ & $\downarrow$ & 0 & $\begin{array}{l}\text { Franciscon et al. } \\
\text { (2009) }\end{array}$ \\
\hline Direct Blue 71 & Ecotoxicity with $D$. Magna & $\uparrow$ & $\uparrow \uparrow$ & 0 & $\begin{array}{l}\text { Franciscon et al. } \\
\text { (2009) }\end{array}$ \\
\hline
\end{tabular}

0 -No toxicity, $\uparrow$ 一 toxicity exists, $\uparrow \uparrow$-toxicity increases as compared to previous stage of treatment, $\downarrow$ - toxicity decreases as compared to previous stage of treatment

structured amines (Lourenco et al. 2001). Moreover, the increase in toxicity after anaerobic treatment of azo dyes and decrease in dissolved organic carbon (DOC) removal may be interpreted as indirect evidence for the formation of aromatic amines (Montano et al. 2008).

Table 3 lists several reactor studies providing evidence for the formation of aromatic amines under anaerobic condition, the method of detection, and the fate of aromatic amines during aerobic biodegradation. Aromatic amines formed from azo dye reduction have been reported to be resistant to anaerobic biodegradation and partially or completely biodegradable under aerobic conditions (Libra et al. 2004; Sponza and Isik 2005; Koupaie et al. 2011; Supaka et al. 2004; Ali 2010; Shaw et al. 2002). The decrease or disappearance of the peaks or shifting towards the lower retention time in the HPLC chromatograms, the decrease or disappearance of aromatic amines as detected by diazotization method, as well as the decrease in UV absorbance; all indicate removal of aromatic amines (Solis et al. 2012). The decrease in toxicity in the effluent of aerobic stage as compared to that with the effluent of anaerobic stage may also provide indirect evidence of degradation of aromatic amines (Isik and Sponza 2004). It may be noted from Table 3 that many of the aromatic amines are removed in the aerobic stage; however, some aromatic amines are found to be resistant. It may be further noted from the results presented in Table 3 that naphthalene-based aromatic amines, such as TAHNDS, $1 \mathrm{~N}-4 \mathrm{~S}$, are either partially degraded or resistant to aerobic biodegradation. On the other hand, most of the benzene-based aromatic amines are completely removed. Tan et al. (2005) studied the fate and biodegradability of benzene-based and naphthalene-based sulphonated aromatic amines in a bioreactor. The authors reported that simple, benzene-based sulphonated amines, such as monoamino benzene sulphonic acid, were completely mineralized while diamino benzene sulphonic acid and other sulphonated amines containing naphthalene were resistant to aerobic biodegradation. Auto-oxidation of aromatic amines during aerobic treatment, as suggested by an increase of colour, has been observed in some of the reactor studies. Auto-oxidation is often a faster process than biodegradation and the compounds are usually recalcitrant and thus not suitable for biological treatment. It has been observed that aromatic amines with ortho-substituted hydroxyl groups are particularly susceptible to auto-oxidation (Vanderzee and Villaverde 2005; Johnstrup et al. 2011; Yasar et al. 2012; Libra et al. 2004; Supaka et al. 2004). 


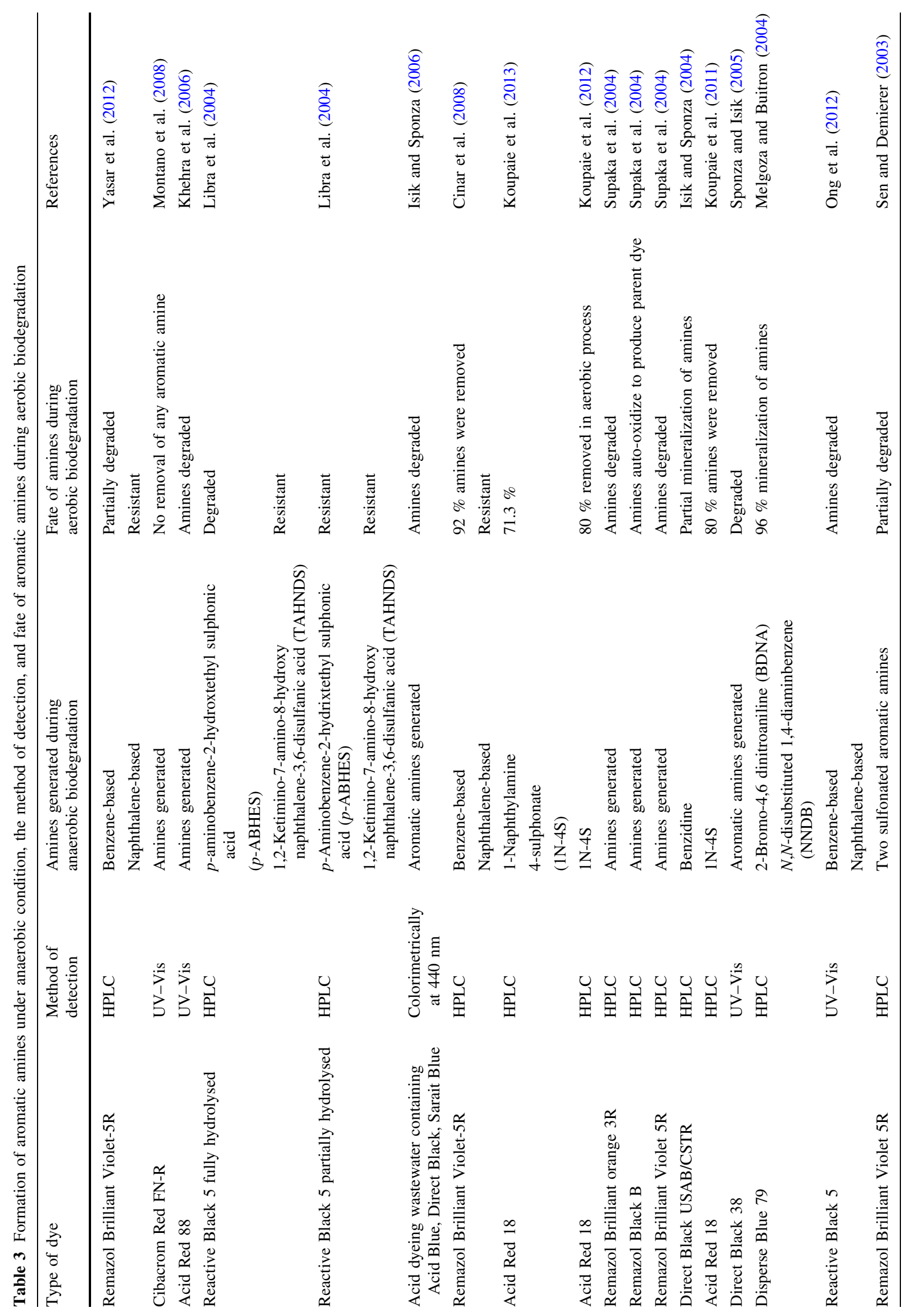




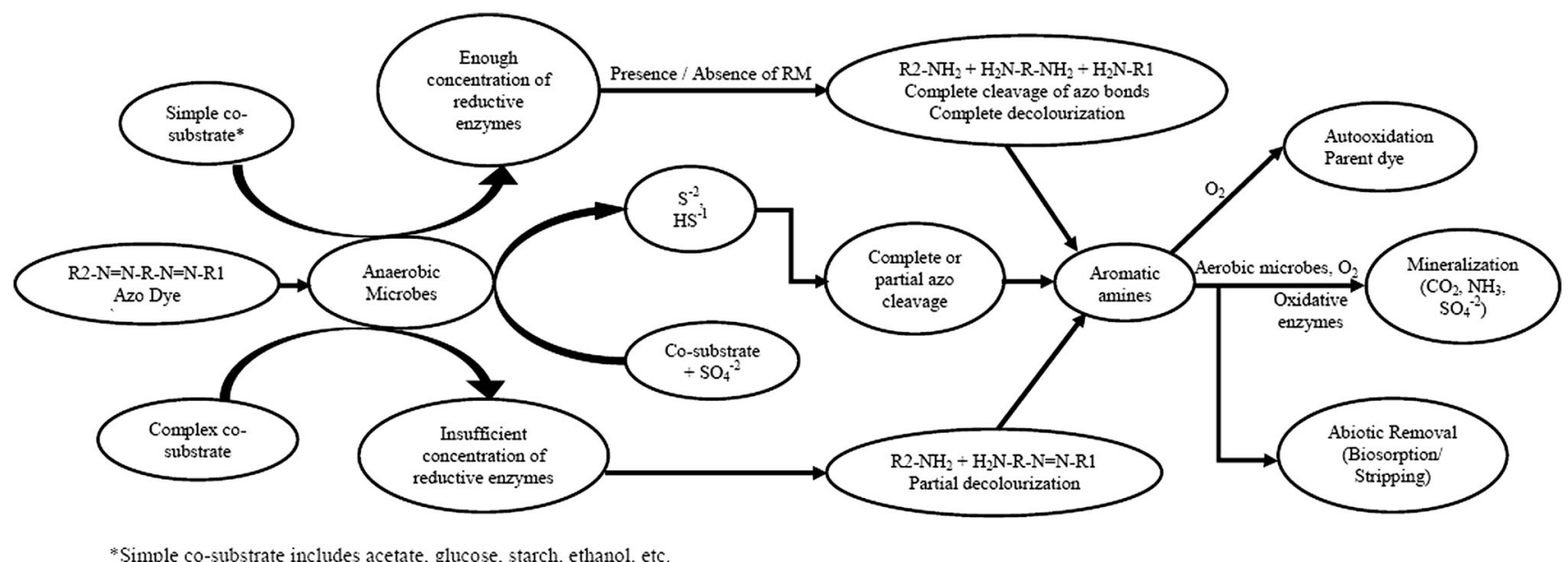

Fig. 3 Schematic illustration of mechanism of decolorization of an azo dye during anaerobic biodegradation and fate of aromatic amines during aerobic biodegradation

Mechanism of biodegradation of azo dyes under sequential anaerobic-aerobic process

Generally, bacterial azo dye biodegradation proceeds in two stages. The first stage involves reductive cleavage of the dyes' azo linkages, resulting in the formation of generally colourless but potentially hazardous-aromatic amines. The second stage involves degradation of the aromatic amines. Azo dye reduction usually requires anaerobic conditions, whereas bacterial biodegradation of aromatic amines is an almost exclusively aerobic process (Vanderzee and Villaverde 2005). The reductive decolourization of azo dyes under anaerobic conditions is nonspecific and presumably extracellular process, in which reductive equivalents from either biological or chemical sources are transformed to the dye (Rauf and Salman Ashraf 2012). Azo dye reduction can take place in a biological process as either a direct enzymatic reaction or a reaction mediated by biologically regenerated enzyme cofactors or other electron carriers like nicotinamide adenine dinucleotide $(\mathrm{NAD}+)$, nicotinamide adenine dinucleotide phosphate (NADP+), etc. generated from various carbon sources are transferred to the dye (Robinson et al. 2001). Moreover, biogenic reductants, such as sulphide, ascorbate, or $\mathrm{Fe}^{2+}$, generated under anaerobic condition may contribute to chemical reduction of azo bonds (Vanderzee et al. 2003). Both biological and chemical azo dye reduction mechanisms have been shown to be greatly accelerated by the addition of RM as discussed earlier. On the other hand, the aromatic amines are degraded aerobically via hydroxylation, and ring cleavage by oxidative enzymes such as peroxidase, laccase, phenoloxidase (Rauf and Salman Ashraf 2012). Laccases have potential in bioremediation due to their non-specific oxidation capacity, lack of a requirement of co-factors, and use of readily available oxygen as an electron acceptor (Solis et al. 2012). The ability of micro-organisms to utilize the amines as the sole source of carbon and nitrogen needs to be checked. The aerobic biological treatment of aromatic amines may result into either auto-oxidized products, and/or complete mineralization leading to formation of $\mathrm{CO}_{2}, \mathrm{NH}_{3}$, etc., and/ or biosorption and volatilization. Based on the parameters discussed under Sect. 3.1 and the foregoing discussion, Fig. 3 illustrates the overall mechanism of biodegradation of azo dyes during sequential anaerobic-aerobic biological treatment.

\section{Conclusion}

Synthetic dyes create environmental pollution and aesthetic problems. Environmental and government regulations are becoming more and more stringent. Hence, there is an urgent need for the technically feasible and cost-effective treatment method. Physical and chemical methods have limitations, such as high cost, low efficiency, limited versatility, and production of secondary sludge. In contrast, biodegradation is a cost-effective, efficient, and ecofriendly method for removal of dyes. The literature reviewed in this paper indicates that sequential anaerobicaerobic biological treatment is a promising method for complete degradation of azo dyes.

Some of the important conclusions that can be drawn from the presented literature review are as under:

- Anaerobic biological decolourization of azo dyes proceed via extracellular reducing enzymes and is positively affected by higher HRT, higher concentration of biomass, simple primary co-substrate (e.g. glucose), and the presence of RM; and negatively 
affected by complexity of dye structure, presence of alternative electron acceptor, and high initial concentration of dye. Above parameters must be optimized in order to achieve the maximum dye decolourization.

- As a result of anaerobic azo bond cleavage, colourless aromatic amines are generated which may or may not be completely mineralized under aerobic conditions and in some cases may increase the toxicity of effluent of anaerobic stage. In general, naphthalene-based aromatic amines are resistant, while benzene-based aromatic amines are amenable to aerobic biodegradation.

\section{Future work}

The method of sequential anaerobic-aerobic treatment of azo dye may be appropriate for the treatment of azo dyes. However, there is still a need to assess the extent of mineralization of aromatic amines which are toxic to human and aquatic life and can undergo auto-oxidation and biosorption. Degradation of many aromatic amines requires presence of specific cultures. Hence, it is necessary to study different pure cultures and mixed cultures in detail for the mineralization of aromatic amines. Molecular biology techniques may also be used for bioaugmentation of aerobic treatment units and to improve the microbial strains so that the rapid mineralization of aromatic amines can be achieved. It may also be necessary to combine AOPs with biological processes to achieve the required degree of treatment of dyecontaining wastewaters so that regulatory standards can be met. Now, that the destruction of pure azo dyes by anaerobic-aerobic biological processes has been established, future research in this area must focus on studies that are closer to real field conditions which involve, for example, effect of copollutants present in textile or dye wastewater, and real industrial wastewater instead of pure dye solutions.

\section{References}

Adinew B (2012) Textile effluent treatment and decolonization techniques-a review. Bulg J Sci Educ 21:434-456

Albuquerque M, Lopes A, Serralheirob M, Novaisa J, Pinheiroa H (2005) Biological sulphate reduction and redox mediator effects on azo dye decolourisation in anaerobic-aerobic sequencing batch reactors. Enzyme Microb Technol 36:790-799

Ali H (2010) Biodegradation of synthetic dyes-a review. Water Air Soil Pollut 213:251-273. doi:10.1007/s11270-010-0382-4

Amin N (2008) Removal of reactive dye from aqueous solutions by adsorption onto activated carbons prepared from sugarcane bagasse pith. Desalination 223:152-161

Anjaneyulu Y, Chary NS, Raj D (2005) Decolourization of industrial effluents-available methods and emerging technologies-a review. Rev Environ Sci Biotechnol 4:245-273
Barraga B, Costa C, Marquez M (2007) Biodegradation of azo dyes by bacteria inoculated on solid media. Dyes Pigm 75:73-81

Bonakdarpour B, Vyrides I, Stuckey D (2011) Comparison of the performance of one stage and two stage sequential anaerobic aerobic biological processes for the treatment of reactive azo dye containing synthetic wastewaters. Int Biodeterior Biodgrad 65:591-599

Boonyakamol A, Imai T, Chairattanamamokom P, Higuchi T, Sekine M (2009) Key factors regarding decolourization of synthetic and anthraquinone and azo dyes. Appl Biochem Biotechnol 158:180-191. doi:10.1007/s12010-008-8330-0

Carvalho M, Pereira C et al (2008) Assessment of the biodegradability of a monosulfonated azo dye and aromatic amines. Int Biodeterior Biodgrad 64:676-681

Chengalroyen M, Dabbs E (2013) The microbial degradation of azo dyes: a mini review. World J Microbiol Biotechnol 29:389-399. doi:10.1007/s11274-012-1198-8

Chequer F, Dortaz D, Oliveira D (2011) Azo dyes and their metabolites: Does the discharge of the azo dyes into water bodies represent Human and Ecological risks? In: Hauser P (ed) Advances in treating textile effluents, ISBN: 978-953-307-704-8, In Tech. http://www.intechopen.com/download/get/type/pdfs/id/ 22392

Chou W, Wang C, Cheng-ping C (2011) Comparison of removal of Acid Orange 7 by electrooxidation using various anode materials. Desalination 266:201-207

Cinar O, Yasar S et al (2008) Effect of cycle time on biodegradation of azo dye in sequencing batch reactor. Process Saf Environ $86: 455-460$

Cirik K, Kitis M, Cinar O (2012) The effect of biological sulfate reduction on anaerobic color removal in anaerobic-aerobic sequencing batch reactors. Bioprocess Biosyst Eng. doi:10.1007/ s00449-012-0813-2

Costa C, Montilla F, Morallon E, Oliyi P (2009) Electrochemical oxidation of acid black 210 dyes on the boron dopes diamond electrode in the presence of phosphate ions: effect of current density, $\mathrm{pH}$ and chloride ions. Electrochim Acta 54:7048-7055

Da Silva M, Firmino P, De Sousa M, Dos Santos A (2012) Sequential anaerobic/aerobic treatment of dye-containing wastewaters: colour and COD removals and Ecotoxicity tests. Appl Biochem Biotechnol 166:1057-1069

Daneshvar N, Oladegaragoze A, Djafarzadeh N (2007) Decolourization of basic dye solutions by electrocoagulation: an investigation of the effect of operational parameters. J Hazard Mater 129:116-124

Daneshwar N, Salari D, Khataee A (2003) Photocatalytic degradation of azo dye Acid Red 14 in water: investigation of the effect of operational parameters. J Photochem Photobiol A 157:111-116

Dos Santos A, Cervantes F, Vanlier J (2007) Review paper on current technologies for decolourisation of textile wastewaters: perspectives for anaerobic biotechnology. Bioresour Technol 98:2369-2385

Forgacs E, Cserhatia T, Oros G (2004) Removal of synthetic dyes from wastewaters: a review. Environ Int 30:953-971

Franciscon E, Zille A et al (2009) Microperophilic-aerobic sequential decolourization/biodegradation of textile azo dyes by a facultative Klebsiella sp. Strain VN-31. Process Biochem 44:446-452

$\mathrm{Fu} \mathrm{Y,} \mathrm{Viraraghavan} \mathrm{T}$ (2001) Fungal decolourization of dye wastewaters: a review. Bioresour Technol 79:251-262

Golob V, Vinder A, Simonic M (2005) Efficiency of the coagulation/ flocculation method for the treatment of dye bath effluents. Dyes Pigm 67:93-97

Gutowska A, Czaplinska J, Jozwiak W (2007) Degradation mechanism of reactive orange 113 dye by $\mathrm{H}_{2} \mathrm{O}_{2} / \mathrm{Fe}^{2+}$ and ozone in aqueous solution. Dyes Pigm 74:41-48 
Hakimelahi M, Moghaddam M, Hashemi S (2012) Biological treatment of wastewater containing an azo dye using mixed culture in alternating anaerobic/aerobic sequencing batch reactors. Biotechnol Bioproc Eng 17:875-880. doi:10.1007/s12257011-0673-7

Hao O, Kim H, Chiang P (2000) Decolourization of wastewater. Crit Rev Environ Sci Technol 30:449-505

Hunger K (2009) Industrial dyes - chemistry, properties, applications. Wiley-VCH, Germany

Inaloo KD, Naddafi K, Mesdaghinia AR, Nasseri S, Nodehi RN, Rahimi A (2011) Optimization of operational parameters for decolorizatoin and degradation of C. I. Reactive Blue 29 by ozone. Iran J Environ Health Sci Eng 8(227):234

Iqbal M (2008) Textile dyes. Rehbar, Karachi

Isik M, Sponza D (2004) Monitoring of toxicity and intermediated of C.I Direct Black 38 azo dye through decolorization in an anaerobic/aeroic sequential reactor system. J Hazard Mater 114:29-39

Isik M, Sponza D (2006) Biological treatment of acid dyeing wastewater using a sequential anaerobic/aerobic reactor system. Enzyme Microb Technol 38:887-892

Johnstrup M, Kumar N, Murto M, Mattiasson B (2011) sequential anaerobic-aerobic treatment of azo dyes: decolourisation and amine degradability. Desalination 280:339-346

Kapdan I, Oztekin R (2006) The effect of hydraulic residence time and initial COD concentration on color and COD removal performance of the anaerobic-aerobic SBR system. J Hazard Mater 136:896-901

Karatas M, Dursun S, Argun M (2009) Decolorization of reactive dyes under batch anaerobic condition by mixed microbial culture. Afr J Biotechnol 8:6856-6862

Karatas M, Dursun S, Argun M (2010) The decolourisation of azo dye Reactive Black 5 in a sequential anaerobic-aerobic system. Ekoloji 19(74):15-23

Khan H, Ahmad N, Yasar A, Shahid R (2010) Advanced oxidative decolourization of red ci-5B: effects of dye concentration, process optimization and reaction kinetics. Polish J Environ Stud 19:83-92

Khan R, Bhawana P, Fulekar M (2013) Microbial decolorization and degradation of synthetic dyes: a review. Rev Environ Sci Biotechnol 12:75-97

Khehra M, Saini H et al (2006) Biodegradation of azo dye C.I. Acid Red 88 by an anoxic-aerobic sequential bioreactor. Dyes Pigm 70:1-7

Koprivanac N, Kusic H (2009) Hazardous organic pollutants in colored wastewaters. Nova Science, New York

Koupaie E, Alavi Moghaddam M, Hashemi S (2011) Post treatment of anaerobically degraded azo dye Acid Red 18 using aerobic moving bed biofilm process: enhanced removal of aromatic amines. J Hazard Mater 195:147-154

Koupaie E, Alavi Moghaddam M, Hashemi S (2012) Investigation of decolourization kinetics and biodegration of azo dye Acid Red 18 using sequencing process of anaerobic sequencing batch reactor/moving bed sequencing batch biofilm reactor. Int Biodeterior Biodgrad 71:43-49

Koupaie E, Alavi Moghaddam M, Hashemi S (2013) Evaluation of integrated anaerobic/aerobic fixed-bed sequencing batch biofilm reactor for decolonization and biodegradation of azo dye Acid Red 18: comparison of using two types of packing media. Bioresour Technol 127:415-421

Laowansiri S, Vinitnantharat S, Chaipraser P, Ha S (2008) Anaerobic degradation kinetics of reactive dye with different carbon sources. J Environ Biol 29:309-314

Libra J, Borchert M, Vigelahn L, Strom T (2004) Two stage biological treatment of a diazo reactive textile dye and the fate of the dye metabolites. Chemosphere 56:167-180
Lourenco N, Novais J, Pinheiro H (2001) Effect of some operational parameters on textile dye biodegradation in a sequencing batch reactor. J Biotechnol 89:163-174

Malik P (2003) Use of activated carbons prepared from sawdust and rice-husk for adsorption of acid dyes: a case study of Acid Yellow 36. Dyes Pigm 56:239-249

Manu B, Chaudhari S (2002) Anaerobic decolorization of simulated textile wastewater containing azo dyes. Bioresour Technol 82:225-231

Martinez-Huitle C, Brillas E (2009) Decontamination of wastewaters containing synthetic organic dyes by electrochemical methods: a General review. Appl Catal B 87:105-145

Mashkour M, Al-Kaim A, Ahmed M, Hussein F (2011) Zinc oxide assisted photocatalytic decolourization of Reactive Red 2 dye. Int J Chem Sci 9:969-979

Melgoza R, Buitron C (2004) Anaerobic/aerobic treatment of colorants present in textile effluents. Water Sci Technol 50:149-155

Mendez-Paz D, Omil F, Lema J (2005) Anaerobic treatment of azo dye Acid Orange 7 under batch conditions. Enzyme Microb Technol 36:264-272

Meric S, Selcuk H, Gallo M, Belgiorno V (2005) Decolourization and detoxifying of Remazol Red and its mixture using Fenton's reagent. Desalination 173:239-248

Mezohegyi G, Kolodkin A, Castr U, Bengoa C, Stuber F, Font J, Fabregat A (2007) Effective anaerobic decolourization of azo dye Acid Orange 7 in continuous upflow packed bed reactor using biological activated carbon system. Ind Eng Chem Res 46:6788-6792

Mohanty S, Dafale N, Rao N (2006) Microbial decolourization of reactive black 5 in a two-stage anaerobic-aerobic reactor using acclimatized activated textile sludge. Biodegradation 17:403-413

Montano J, Domenche X, Hortal G, Torrades F, Peral J (2008) The testing of several biological and chemical coupled treatments for Cibacron Red FN-R azo dye removal. J Hazard Mater 154:484-490

Mutambanengwe C, Togo C, Whiteley C (2007) Decolourization and degradation of textile dyes with biosulfidogenichydrogenases. Biotechnol Prog 23:1095-1100

Naimabadi A, Attar H, Shahsavani A (2009) Decolorization and biological degradation of azo dye Reactive Red 2 by anaerobic/ aerobic sequential process. Iran J Environ Health Sci Eng 6:67-72

O'Neill C, Hawkes F, Hawkes D, Esteves S, Wilcox S (2000) Anaerobic-aerobic biotreatment of simulated textile effluent containing varied ratios of starch and azo dye. Water Res 34:2355-2361

Oh Y, Kim Y et al (2004) Colour removal of real textile wastewater by sequential anaerobic and aerobic reactors. Biotechnol Bioproc Eng 9:419-422

Oller I, Malato S, Sanchez-perez J (2011) Combination of advanced oxidation processes and biological treatments for wastewater decontamination-a review. Sci Total Environ 409:4141-4166

Ong S, Li H, Wong Y, Raman K (2012) Performance and kinetic study on bioremediation of diazo dye Reactive Black 5 in wastewater using spent GAC-Biofilm sequencing batch reactor. Water Air Soil Pollut 223:1615-1623

Pandey A, Singh P, Iyengar L (2007) Review: bacterial decolourization and degradation of azo dyes. Int Biodeterior Biodgrad 59:73-84

Panswad T, Luangdilok W (2000) Decolorization of reactive dyes with different molecular structures under different environmental conditions. Water Res 34:4177-4184

Patel T, Nath K (2012) Comparative performance of flat sheet and spiral wound modules in the nanofiltration of reactive dye solution. Env Sci Pollution Res 19:2994-3004 
Patel U, Ruparelia J, Patel M (2011) Electrocoagulation treatment of simulated floor-wash containing Reactive Black 5 using iron sacrificial anode. J Hazard Mater 197:128-136

Petrinic I, Andersen N, Sostar-turk S, Le Marechal M (2007) The removal of reactive dye printing compound using nanofiltration. Dyes Pigm 74:512-518

Phalakornkule C, Polgumhang S, Tongdaung W, Karakat B, Nuyut T (2010) Electrocoagulations of blue reactive, red disperse and mixed dyes, and application in treating textile effluent. J Environ Manag 91:918-926

Puvaneshwari N, Muthukrishnan J, Gunasekaran P (2006) Toxicity assessment and microbial degradation of azo dyes. Indian J Exp Biol 44:618-626

Rai H, Bhattacharya M et al (2005) Removal of dyes from the effluent of textile and dyestuff manufacturing industry: a review of emerging techniques with reference to biological treatment. Crit Rev Environ Sci Technol 35:219-238

Rajaguru P, Kaileselvi K, Palanivel M, Subburum V (2000) Biodegradation of azo dyes in sequential anaerobic-aerobic system. Appl Microbial Biotechnol 54:268-273

Rauf M, Salman Ashraf S (2012) Review: survey of recent trends in biochemically assisted degradation of dyes. Chem Eng $\mathrm{J}$ 209:520-530

Robinson T, Mcmullan G, Marchant R, Nigam P (2001) Remediation of dyes in textile effluent: a critical review on current treatment technologies with a proposed alternative. Bioresour Technol 77:247-255

Sandhya S, Padmavathy S, Swaminathan K, Subrahmanyam Y, Kaul S (2005) Microaerophilic-aerobic sequential batch reactor for treatment of azo dyes containing simulated wastewater. Proc Biochem 40:885-890

Saratale R, Saratale G, Chang J, Govindwar S (2011) Bacterial decolourization and degradation of azo dyes: a review. J Taiwan Inst Chem Eng 42:138-157

Sen S, Demierer G (2003) Anaerobic treatment of synthetic textile wastewater containing a reactive azo dye. J Environ Eng 129:595-601

Senthikumar S, Bashab C, Perumalsamya M, Prabhua H (2012) Electrochemical oxidation and aerobic biodegradation with isolated bacterial strains for dye wastewater. Electrochim Acta $77: 171-178$

Sharma BK (2011) Industrial chemistry. Goel Publishing House, India

Shaw C, Carliell C, Wheatley A (2002) Anaerobic/aerobic treatment of coloured textile effluents using sequencing batch reactors. Water Res 36:1993-2001

Solis M, Solis A, Perez H, Manjarrezb N, Floresa M (2012) Microbial decolouration of azo dyes: a review. Process Biochem 47:1723-1748

Spagni A, Grilli S, Casu S, Mattioli D (2010) Treatment of a simulated textile wastewater containing the azo-dye Reactive Orange 16 in an anaerobic-biofilm anoxic-aerobic membrane bioreactor. Int Biodeterior Biodgrad 64:676-681

Sponza D, Isik M (2002) Decolourization and azo dye degradation by anaerobic/aerobic sequential process. Enzyme Microb Technol $31: 102-110$

Sponza D, Isik M (2004) Decolorization and inhibition kinetic of Direct Black 38 azo dye with granulated anaerobic sludge. Enzyme Microb Technol 34:147-158
Sponza D, Isik M (2005) Reactor performances and fate of aromatic amines through decolorization of Direct Black 38 dye under anaerobic/aerobic sequentials. Process Biochem 40:35-44

Supaka N, Juntongjin K, Damronglerd S, Delia M, Strehaiano P (2004) Microbial decolorization of reactive azo dyes in a sequential anaerobic-aerobic system. Chem Eng J 99:169-176

Talarposhti A, Donnelly T, Andersonm G (2001) Colour removal from a simulated dye wastewater using a two-phase anaerobic packed bed reactor. Water Res 35:425-432

Taplad T, Neramittagapong A, Neramittagapong S, Boonmee M (2008) Degradation of Congo Red dye by ozonation. Chiang Mai J Sci 35:63-68

Tan CG, Leewen A, VanVoorthuizen E et al (2005) Fate and biodegradation of sulfonated aromatic amines. Biodegradation 16:527-537

Uliana C, Garbellini G, Yamanaka H (2012) Electrochemical reduction of disperse orange 1 textile dye at a boron-doped diamond electrode. J Appl Electrochem 42:297-304

Vanderzee F, Cervantes F (2009) Impact and application of electron shuttles on the redox (bio) transformation of contaminants: a review. Biotechnol Adv 27:256-277

Vanderzee F, Villaverde S (2005) Combined anaerobic-aerobic treatment of azo dyes - a short review of bioreactor studies. Water Res 39:1425-1440

Vanderzee F, Lettinga G, Field J (2001) Anaerobic decolourization by granular sludge. Chemoshere 44(1169): 1176

Vanderzee F, Bisschops L, Blanchardb VG, Bouwman R, Lettinga G, Field J (2003) The contribution of biotic and abiotic processes during azo dye reduction in anaerobic sludge. Water Res 37:3098-3109

Velmurugan P, Kumar R, Dhinakaran G (2011) Dye removal from aqueous solution using low cost adsorbent. Int $\mathrm{J}$ Envrion Sci 1:1493-1503

Vijaya P, Sandhya S (2003) Decolourization and complete degradation of methyl red by a mixed culture. Environmentalist 23:145-149

Wang C, Yedilar A, Lienert D, Wang Z, Kettrup A (2002) Toxicity evaluation of reactive dyestuffs, auxiliaries and selected effluents in textile finishing industry to luminescent bacteria Vibrio Fischeri. Chemosphere 46:339-344

Wong P, Tow T, Abdul Rahman N (2007) Efficiency of the coagulation-flocculation method for the treatment of dye mixtures containing disperse and reactive dyes. Water Qual Res J Canada 42:1

Yasar S, Cirik K, Cinar O (2012) The effect of cyclic anaerobicaerobic conditions on biodegradation of azo dyes. Bioproc Biosyst Eng 35:449-457. doi:10.1007/s00449-011-0584-1

You S, Teng J (2009) Anaerobic decolourization bacteria for the treatment of azo dye in a sequential anaerobic and aerobic membrane bioreactor. J Taiwan Inst Chem Eng 40:500-504

Young-kim S, Young-An J, Wookim B (2007) Improvement of the decolourization of azo dye by anaerobic sludge bioaugmented with Desulfovibrio desulfuricans. Biotechnol Bioprocess Eng $12: 222-227$ 